\title{
A regional action plan to promote the health of migrants, refugees and displaced populations ${ }^{1}$
}

Citation: A regional action plan to promote the health of migrants, refugees and displaced populations. East Mediterr Health J. 2019;25(5):xx https://doi. $\operatorname{org} / 10.26719 / 2019.25 \cdot 5 \cdot 366$

Copyright @ World Health Organization (WHO) 2019. Some rights reserved. This work is available under the CC BY-NC-SA 3.0 IGO license (https:// creativecommons.org/licenses/by-nc-sa/3.o/igo).

\section{Introduction}

Migrants, refugees and displaced populations are often among the most vulnerable of society's members. Despite international conventions and resolutions, many lack access to healthcare services, including health promotion, disease prevention, and treatment and care, as well as to financial protection. The proportion of the global population classified as international migrants increased from $2.9 \%$ in 2005 to $3.4 \%$ in 2017 , while the overall number of international migrants increased from an estimated 153 million in 1990 to 258 million in 2017 (1). The Office of the United Nations High Commissioner for Refugees (UN$\mathrm{HCR}$ ) reports that, globally, the number of forcibly displaced people is 68.5 million - the highest level of human displacement ever, and includes 25.4 million refugees (2). There are also 10 million stateless people who lack a nationality and access to basic rights such as education, healthcare, employment and freedom of movement (2).

The World Health Organization Eastern Mediterranean Region (WHO/EMR) is the WHO region with the largest presence of refugees and displaced populations. Currently, the Region hosts 66\% (16.7 million) of the total number of refugees worldwide (25.4 million) and 33\% (1 million) of the world's asylum seekers (3.1 million) (1,2). In addition, the Palestinian refugee population has reached almost 5.2 million people living in camps and host communities between Jordan, Lebanon, Syrian Arab Republic, West Bank and Gaza Strip (2).

In May 2017, the Seventieth World Health Assembly endorsed resolution WHA70.15, which called for the promotion of the health of refugees and migrants (3) in line with the New York Declaration for Refugees and Migrants (4). WHO, at the request of its Member States, began a two-year consultative process with national and international stakeholders that has resulted in the Draft Global Action Plan 2019-2023 (5), which builds on resolution WHA70.

In this context, a regional meeting to develop a regional action plan for promoting the health of migrants, refugees and displaced populations was convened by WHO in Istanbul, Turkey, 25-27 March 2019 (6). The objectives of the meeting were to:

- present and discuss outcomes of assessment of health needs of migrants ${ }^{2}$ conducted in countries in the Region;
- present the Draft Global Action Plan to promote the health of migrants and the health provisions of the endorsed global compacts; and

- present the draft regional action plan to promote the health of migrants and finalize its development.

In his message to the opening session of the meeting, Dr Ahmed AlMandhari, WHO Regional Director for the Eastern Mediterranean, reminded participants of the conflicts that have plagued the Region for decades, leaving migrants without basic services. He noted that this had put a strain on the resources of countries experiencing conflict and neighbouring states that had welcomed these vulnerable populations.

\section{Summary of discussions}

Discussions focused on the issue of universal health coverage and different models of health financing, such as insurance schemes and the importance of adopting a rights-based approach across all countries. The availability and usage of disaggregated data was also discussed, looking at occupational diseases among migrants and WHO methods for monitoring occupational diseases and the role of national statistical bureaus in relation to data disaggregation. In addition, the notion of specific health services for migrants was examined, or whether they should be integrated into existing health services. It was felt that existing services should be expanded and strengthened to provide adequate prevention and management of non-communicable diseases and mental health and psychosocial support.

The proposed regional action plan was presented and discussed. Its vision was highlighted, as inclusive of all members of society, including migrants, to have the rights and means to enjoy the highest attainable standard of health and well-being, without fear of discrimination. The regional action plan aims to build human mobility-competent preparedness and response, and health systems, in areas affected by displacement and migration.

Moreover, the assessment of the long-term public health of migrants was emphasized, and calls to explore the institutional capacity of countries hosting such populations and their ability to deliver healthcare services to vulnerable populations was deliberated. WHO

\footnotetext{
Regional meeting to develop a regional action plan to promote the health of migrants, refugees and displaced populations, Istanbul, Turkey, 25-27 March 2019 (http://applications.emro.who.int/docs/IC_Meet_Rep_2019_EN_23541.pdf?ua=1).

${ }^{2}$ The description 'migrants' here includes refugees and displaced populations.
} 
is currently finalizing an assessment tool for this purpose that follows a three phase approach: a preparatory phase (initiating the process, developing a concept note, drafting an agenda for the mission, completing the essential public health functions assessment); work on the ground (an orientation meeting, a stakeholder meeting to validate the essential public health functions assessment, facility-level assessments, focus group discussions, and a debriefing with all stakeholders); and finalizing the plan of action.

\section{Recommendations}

\section{To Member States}

1. Designating a focal point to follow up on the regional action plan and be the point of contact for WHO for collecting input and feedback on the plan.

2. Adapting the WHO public health assessment tool for migration, when finalized, to the national context and conduct assessments.

3. Including migrant, refugee and displaced population health in the health planning system and integrate it within existing and future national health strategies.

\section{To WHO}

4. Finalizing the WHO public health assessment tool for migration and continuing to roll out assessments in countries upon request.

5. Finalizing the regional core indicators to include disaggregation of data by agreed-upon variables that will allow monitoring for the health of migrants, refugees and displaced populations.

6. Coordinating with partners (including United Nations agencies) for revision of the regional action plan.

\section{References}

1. United Nations. Population facts no 2017/5. New York: United Nations; December 2017 (https://www.un.org/en/development/ desa/population/publications/pdf/popfacts/PopFacts_2017-5.pdf).

2. UN Refugee Agency (UNHCR). Figures at a glance. New York: UNHCR; 2017 (https://www.unhcr.org/figures-at-a-glance.html).

3. Seventieth World Health Assembly. Promoting the health of refugees and migrants (resolution WHA70.15). Geneva: World Health Organization; 2017 (http://apps.who.int/gb/ebwha/pdf_files/WHA70/A70_R15-en.pdf).

4. United Nations: New York declaration for refugees and migrants (resolution 71/1). New York: United Nations; 2016 (https:// www.un.org/en/development/desa/population/migration/generalassembly/docs/globalcompact/A_RES_71_1.pdf).

5. Seventy-Second World Health Assembly. Draft global action plan 2019-2023, promoting the health of refugees and migrants. Geneva: World Health Organization; 2019 (https://apps.who.int/gb/ebwha/pdf_files/WHA72/A72_25-en.pdf).

6. Regional meeting to develop a regional action plan to promote the health of migrants, refugees and displaced populations, Istanbul, Turkey, 25-27 March 2019 (http://applications.emro.who.int/docs/IC_Meet_Rep_2019_EN_23541.pdf?ua=1). 